\title{
Survey
}

Nadine Riedel*

\section{Quantifying International Tax Avoidance: A Review of the Academic Literature}

https://doi.org/10.1515/roe-2018-0004

\begin{abstract}
This paper provides a brief review of the academic literature that assesses the quantitative importance of tax avoidance behaviour of multinational entities (MNEs) by means of income shifting from high-tax to low-tax affiliates. Existing studies unanimously report evidence in line with tax-motivated profit shifting (despite using different data sources and estimation strategies). In terms of shifting channels, there is evidence consistent with strategic mispricing of intra-firm trade, the location of valuable intellectual property at low-tax affiliates and debt-shifting activities. The quantitative estimates vary across approaches and studies though. The paper moreover stresses that some care should be warranted when interpreting profit shifting estimates as they often rely on non-trivial assumptions.
\end{abstract}

Keywords: Multinational firms, profit shifting, survey

JEL Classification: H2, H7

\section{Introduction}

With the emergence of the financial crisis and increasing fiscal strains in many countries, reports of multinational enterprises (MNEs) like Google, Apple, Starbucks and Ikea engaging in significant international tax avoidance activities triggered public outrage, with the media, NGOs and politicians heavily criticizing their "lousy behaviour" (Larry Elliot in The Guardian (2013)) and labelling them to be modern "Robber Barons" (John Simpson in The Telegraph (2012)).

Companies defended themselves by stressing that they fully abided by the tax law and that it is the role of the legislator to close existing loopholes for multinational tax avoidance activities. Anecdotal evidence points to many of these loopholes and suggests that firms set up complicated international tax structures to shift income from high-tax to low-tax locations, including the mis-pricing of intra-firm trade, the strategic location of valuable intellectual property (IP) at low-

*Corresponding author: Nadine Riedel, Fak für Wirtschaftswissenschaft, Ruhr University Bochum, Bochum, Germany, E-mail: Nadine.Riedel@rub.de 
tax affiliates and debt-shifting arrangements, where low-tax entities lend to hightax affiliates to strip out tax-deductible interest payments. ${ }^{1}$ Mandated by the G20, the OECD responded to public concerns about this type of aggressive international tax avoidance and developed an action plan to combat base erosion and profit shifting, which was endorsed by the G20 group in 2015.

As many anti-shifting provisions do not only deter MNEs' tax planning schemes but may also distort underlying business activity, increase firms' double taxation risk and raise compliance and enforcement costs, their welfare consequences depend on the extent to which MNEs actually do engage in tax avoidance behaviour. Against this background, the purpose of this paper is to go back one step and ask whether profit shifting is indeed a systematic and quantitatively important phenomenon that goes beyond the singular cases that were prominently featured in the media.

\section{Descriptive evidence}

One may be tempted to jump to conclusions very quickly and argue that the observed presence of many MNEs in tax haven countries and their low aggregate effective corporate tax rates already prove the point. ${ }^{2}$ Some words of caution are warranted though. Low effective tax rates may also (partly) relate to nonavoidance activities, e. g. to high levels of tax-deductible investment expenses or loss-carryforwards. Tax havens moreover do not only woo firms with low tax

\footnotetext{
1 One prominent scheme is the so-called "Double Irish Dutch Sandwich“, where a US-based multinational avoids the high corporate tax rates in European markets by selling its products from an Irish subsidiary. To further reduce the $12.5 \%$-tax rate charged in Ireland, the firm transfers patents to a subsidiary in a haven economy with a zero rate, e. g. Bermuda, and strips income out of Ireland through royalty and license payments. To avoid withholding taxes, the money is furthermore channeled through a conduit in the Netherlands, exploiting the absence of withholding taxes under Dutch law. Finally, the group maneuvers around the application of US controlled foreign company (CFC) rules by founding a second Irish affiliate managed by the Bermudian subsidiary, exploiting that the firm is tax resident in Ireland under US law and tax resident in Bermuda under Irish law (e. g. IMF (2013)). Changes in the Irish tax residence rules in 2015, however, sounded the death knell to the schemes.

2 DESAI, Foley, AND Hines (2006) present evidence that in 1999 more than every second USbased MNE had some presence in countries that appear on standard tax-haven lists (see DHARMAPAla AND HinES (2009)). GUMPERT, HinES, AND SCHNitZER (2011) report a smaller figure for German-based MNEs ( $25 \%$ ), which may relate to reporting thresholds that prevent the authors from observing small foreign entities in haven economies. Aggregate BEA data furthermore suggest that about $40 \%$ of (foreign) net income of US firms is located in tax havens (Dharmapala (2014)).
} 
rates but often provide good governance institutions, attractive public infrastructure and well-developed financial service and labour markets (see e.g. the economically important tax havens of Switzerland and Ireland). The corporate decision to locate investments in these countries may thus be driven by other determinants than corporate tax avoidance considerations.

\section{Indirect evidence: pre-tax profits and corporate tax rates}

Researchers have thus tried to develop better empirical strategies to identify multinational shifting behaviour. As MNEs have an incentive to hide avoidance activities from the public and corporate reporting requirements do not establish full transparency, existing strategies are necessarily indirect and present no "smoking gun" in the narrow sense of the word.

The most common approach pursued in the literature is to compare pre-tax profits of high-tax and low-tax affiliates as income shifting reduces the former and increases the latter. Survey evidence for US MNEs (provided by Bureau of Economic Analysis (BEA)) for example points to strongly elevated pre-tax profitability rates at tax-haven affiliates (see e. g. SuLLIVAN (2004) and CLAUSING (2011)). Unfortunately, this pattern may also be an artefact of the BEA's data structure (see ALTSHULER AND GRUBERT (2006) and footnote 3 for details) ${ }^{3}$ or may reflect variation in other profitdeterminants that differ across host countries and affiliates (e.g. differences in worker productivity, public good provision or market competition).

The literature accounted for these shortcomings by making use of other firm databases (often drawing on accounting information) and by estimating empirical models that control for country and affiliate-specific profit-determinants. While early papers compare pre-tax profitabilities of high-tax and low-tax affiliates, more recent papers analysed changes in affiliates' reported pre-tax profitability in response to corporate tax reforms. The benefit of the latter approach is that time-constant unobserved differences across entities cannot confound the results.

3 Problems may arise as foreign affiliates' pre-tax income in the BEA data includes income from equity investments, which might trigger 'double-counting' of income and artificial profits at low-tax locations (if they host holding companies). To see this, imagine a US parent with a holding company in a tax haven and a manufacturing affiliate in a foreign high-tax country. The manufacturing firm earns US $\$ 1000$, subject to a $40 \%$ corporation tax, and remits the full US $\$ 600$ to the holding company in the tax haven in form of dividends. The BEA data then shows US $\$ 600$ of after-tax profits in both affiliates. See ALTSHULER AND GRUBERT (2006) and DHARMAPALA (2014). 
Studies unanimously report an inverse relation between the corporate tax rate (difference) and affiliates' reported pre-tax profits. The size of the estimates varies across papers though. HECKEMEYER AND OVERESCH (2017) conduct a meta-analysis and present a semi-elasticity of 0.8 as a consensus estimate, implying that an increase in the host country's corporate tax (difference to foreign group locations) of 10 percentage points lowers affiliates' reported pretax profits by $8 \%$. Thus, from every 1000 Euros earned at a high-tax location, MNEs would transfer 80 additional Euros to lower-tax entities after the increase in the corporate tax rate (differential).

While these findings are commonly interpreted as evidence for multinational income shifting, a number of caveats have to be kept in mind. To see this, let's do a thought experiment and assume that MNEs did not engage in income shifting. Are there other mechanisms that may establish a link between corporate taxes and affiliates' reported pre-tax profitability? Three candidates:

Firstly, MNEs may have an incentive to strategically sort high return projects to low-tax affiliates and vice versa. While no separation of economic activity and taxable income ("paper profit shifting") is involved, the mechanism establishes a negative correlation between corporate taxes and reported pre-tax profitability. Secondly, high corporate taxes may imply that MNEs require a higher pre-tax return in order to invest in a country, which establishes a positive correlation between taxes and reported pre-tax profitability. Thirdly, corporate taxation may affect affiliates' pre-tax profits through changes in effort provision. ${ }^{4}$ As owners can keep less of earned income when corporate taxes rise, manager-owners may exert less effort or, with separation of management and ownership, adjust staff's incentive contracts. Again, this gives rise to a negative correlation between pretax profits and corporate tax rates. ${ }^{5}$

Interpreting the above estimates as evidence for paper profit shifting hence assumes that these mechanisms are of minor importance. If they are not, the estimates may understate (see second argument) or overstate (see first and third argument) the true extent of profit shifting. ${ }^{6}$

4 Note that the first argument refers to MNEs that are subject to financing or operational constraints and for that reason implement a given set of projects only. The second argument in turn refers to unconstrained MNEs.

5 Other sources of bias include a lack of book-tax conformity (when studies rely on accounting data) and worldwide taxation. Moreover, due to reporting exemptions many official and private data sources do not include small firms. If shifting activities vary with entity size, existing estimates are not representative for the population of firms.

6 Note that modelling the tax incentive by the corporate tax rate differential between group affiliates does not solve (all of) these issues. Specifically, variation in the tax rate differential is either induced by changes in the host country tax or by changes in the tax rate at foreign group 
The approach has been used to quantify the revenue losses from income shifting for the US. CLAUSING $(2009,2011)$ ) estimates that revenue costs in 2004 and 2008 amounted to $\$ 60$ and $\$ 90$ billion respectively or about $30 \%$ of US corporate tax revenues. The findings should be interpreted with some care though since the above methodological caveats apply and the tax-sensitivity of corporate profits underlying Clausing's estimates is large compared to other papers (3.3 relative to the 0.8-semi-elasticity consensus estimate in HECKEMEYER AND OVERESCH (2017)). ${ }^{7}$ Based on a similar approach, the final report for the OECD BEPS Action 11 estimates that the global corporate tax revenue lost from BEPS amounts to $\$ 100-240$ billion or $4-10 \%$ of corporate tax revenues (OECD (2015)).

\section{Alternative approaches: profitability shocks and corporate twins}

The literature has proposed two alternative approaches to test for multinational income shifting. Both approaches do not rely on identification based on variation in corporate tax rates and are hence not prone to the identification concerns sketched above.

locations. Identification through the former involves all problems described above; identification through the latter is not subject to the second and third alternative mechanism, but to the first. Moreover, as shifting-partners cannot be directly observed, studies commonly model the tax difference using a(n) (weighted) average of foreign affiliates' tax rates. Since many affiliates are, however, not part of a firm's shifting network, this is a noisy measure and may result in a downward bias of the estimate, making the direction of the overall bias unclear. Note, however, that modelling MNEs' shifting incentives by the tax rate differential is nevertheless preferred relative to models that account for the affiliate's host country tax rate only as disregarding foreign taxes may distort the shifting estimate for two reasons: Firstly, if MNEs found new (close existing) low-tax affiliates in response to corporate tax increases (decreases), the change in the tax rate differential is larger than the change in the host country tax, which implies shifting estimates to be too large if the foreign tax rate is omitted. If, in turn, in line with international tax competition, tax decreases in one country trigger tax decreases in neighboring economies, the change in the tax differential is smaller than the change in the host country tax, implying estimates to be too small if foreign taxes are omitted.

7 DOWD, LANDEFELD, AND MOORE (2017) furthermore estimate the response of pre-tax profits to corporate taxes but allow for heterogeneity in the response rate across the distribution of corporate tax rates. Their findings suggest that elasticities based on a log-linear specification may severely understate the sensitivity of profits to tax in low-tax jurisdictions while simultaneously overstating this elasticity in high-tax jurisdictions. 
The first approach, proposed by DHARMAPALA AND RIEDEL (2013), exploits profitability shocks to multinational affiliates as a source for empirical identification. The authors argue that, if MNEs engage in tax-motivated income shifting, positive profit shocks at high-tax locations should partly translate into higher reported income at the group's low-tax affiliates (but not at other high-tax affiliates). Using data on European firms, profitability shocks are modelled by changes in industry profitability in a given country. The findings suggest that MNEs shift around $2 \%$ of the additional income to lower tax entities. Three features of the data and model set-up suggest that the estimate is a lower bound to the true effect: firstly, the authors construct profit shocks to parent firms and investigate whether these are transmitted to lower-tax subsidiaries. Previous papers (DISCHINGER, KNOLL, AND RIEDEL (2014)) suggest though that MNEs are more reluctant to shift income away from their headquarters location than from high-tax subsidiaries. Secondly, the observed average tax rate differential between parents and lower-tax subsidiaries is relatively small in the authors' data, implying limited shifting incentives. Thirdly, for conceptual reasons, the study disregards subsidiaries that operate in the same industry as their parent (since they may be subject to the same profitability shock). If a significant fraction of profit shifting takes place between entities in the same sub-industry, e. g. related to high levels of intra-firm trade and much leeway in setting taxfavorable transfer prices, this is not captured in the analysis and observed profit relocations may mainly reflect debt-shifting behavior. ${ }^{8}$

The second alternative approach to quantify tax losses through international income shifting was proposed by EGGER, EGGERT, AND WINNER (2010) and FINKE (2013). Using firm level data for Europe and Germany respectively, the authors aim to identify income-shifting behaviour by comparing corporate tax payments of multinational and national enterprises (NEs). As MNEs and NEs may differ in various other tax-determining characteristics, the authors employ matching techniques to identify similar twins in the two subgroups (as determined by firm characteristics, e.g. age, size, industry and productivity as well as host region characteristics). Both papers report large differences between corporate taxes paid by comparable MNEs and NEs. Egger et al. find that, in European high-tax countries, the corporate tax burden on MNEs is more than $30 \%$ lower than the burden on NEs. For Germany, FINKE (2013) suggests a gap of $27 \%$ in 2007, which declined after the 2008 corporate tax reform, presumably related to the reduction

8 The tax sensitivity approach presented in the previous section predicts that in DHARMAPALA AND RIEDEL (2013)'s sample around 4\% of additional income is shifted to low-tax entities ( = average corporate tax rate difference of $7.7 \%$ between sample affiliates times the profit-tax semi-elasticity estimate of 0.5 reported in DISCHINGER, KNOLL, AND RIEDEL (2014)). 
in the headline corporate tax rate and the implementation of tighter thin-capitalization rules. The Achilles' heel of the approach is that these matching estimates are biased if tax-determinants, which are unobserved by researchers, systematically differ between MNEs and NEs. MNEs' managements may e. g. be more aggressive in exploiting tax-planning opportunities than NEs' managements. MNEs may also engage in more extensive government lobbying than NEs and, in consequence, receive more firm-specific tax benefits (e.g. through laxer tax audits). ${ }^{9}$ On top, to prevent mobile MNEs from relocating investment to foreign countries, governments may grant firm-specific tax reductions to multinationals (as acknowledged in EGGER, EGGERT, AND WINNER (2010)). All three arguments suggest that part of the observed gap in tax payments may be driven by other mechanisms than international tax avoidance of MNEs.

\section{Other estimates: tax authorities and ngos}

On top, several tax authorities estimate corporate tax revenue gaps related to avoidance behaviour (commonly not distinguishing between international and national avoidance though - or even pooling avoidance activities with illegal evasion, filing errors and criminal activity). In the United Kingdom, the British HM Revenue and Customs (HMRC) determined a tax avoidance gap for large businesses of $€ 1.1$ billion in 2012/13 or 5\% of the firms' theoretical tax liabilities (£0.1 billion for small and medium-sized firms), see HMRC (2014). ${ }^{10}$ This is likely a lower bound to the true gap as their analysis relies on internal knowledge from HMRC's case management systems and tax specialists are unlikely to identify all avoidance schemes.

As an alternative strategy, TUC (2008) and The Guardian (2009) proposed to quantify revenue losses from multinational tax avoidance for the UK by comparing the amount of tax paid as declared in firms' accounts with an estimate of the tax due. As stressed in MiLler (2013) and others, the shortcoming of this approach is that it does not account for the deliberate elements in the structure of the tax system that lead to a reduction in tax liabilities (such as capital allowances, the R\&D tax credit and loss carry-forwards) or the genuine commercial reasons why taxes may be paid in other jurisdictions. Thus, while their tax

\footnotetext{
9 If lobbying for example involved fixed costs, only groups above a given size threshold would engage in lobbying (which are then also often MNEs), see e. g. BOMBARDINI (2008).

10 Large firm's tax avoidance hence contributes the lion's share to the total corporation tax gap of $£ 3.9$ billion.
} 
gap estimates are substantially larger than those in the HMRC analysis - for 2006, TUC (2008) e. g. estimates an avoidance gap of $€ 12$ billion in the UK - they are likely overstated (and possibly by a wide margin). ${ }^{11}$

\section{Analysing specific relocation channels}

Another strand of the literature tries to account for the discussed shortcomings by investigating specific income shifting channels. As sketched in the Introduction, prominent international tax avoidance strategies include the mispricing of intra-firm trade, strategic location of valuable IP at low-tax locations and debt-shifting activities. ${ }^{12}$

The literature on tax-motivated distortions of MNEs' transfer prices compares prices for intra-firm and extra-firm trade within specific industries or product groups. The seminal work by CLAUSING (2003) uses US trade data and finds that a 1\%-drop in the foreign tax rate reduces intra-firm export prices by a large $1.8 \%$. BERNARD, JENSEN, AND SCHOTT (2006) confirm this result. ${ }^{13}$ CRISTEA AND NGUYEN (2016) study trade pricing of Danish firms before and after they set up their first foreign subsidiary. ${ }^{14}$ After owning an affiliate in a low-tax country,

11 NGOs also published estimates for the income tax gap related to both, illegal tax evasion and avoidance (of firms and individuals). MURPHY (2012) claims that the income tax gap in the European Union exceeds 1 trillion Euro, accounting for evasion and avoidance activities of firms and individuals. The lion's share of his estimate relates to tax evasion. Losses due to tax avoidance are quantified with 150 billion Euros per year. The number is based on a simple average of tax authority estimates and the methodology in TUC (2008) and may, for the reasons stated above, over- or underestimate the actual revenue loss.

12 Other international tax avoidance channels include tax treaty shopping and hybrid mismatch arrangements. There is, to the best of our knowledge, no systematic empirical evidence on hybrid mismatch arrangements (see also JoHANNESEN (2014)). COLLINS AND SHACKELFORD (1997), Desai, Foley, ANd Hines (2003) and WeichenRIEDER AND Mintz (2008) present empirical evidence in line with treaty shopping activities.

13 Clausing's results may be biased if MNEs and NEs trade systematically different goods (e. g. in terms of quality) within the same product and industry group respectively. BERNARD, JENSEN, AND SCHOTT (2006) account for this shortcoming by using data on US export prices linked to firm-level information. Comparing intra-firm and extra-firm trade of the same firm, they find a large average price wedge of $43 \%$, which also depends on foreign tax rates.

14 CRISTEA AND NGUYEN (2016) argue that MNEs have a strategic incentive to deviate the export price on extra-firm trade from its profit maximizing level to a value closer to the transfer price of intra-firm trade in order to comply with the arm's length principle of taxation. While this leads to an underestimation of the mispricing effect in the BERNARD, JENSEN, AND SCHOTT (2006) paper, CRISTEA AND NGUYEN (2016)'s approach is immune to this concern. 
MNEs are found to reduce prices for exports from Denmark by 5.7 percent. The associated loss in tax income equals 3.2\% of Danish MNEs' tax returns. This is likely a lower bound to the true effect though as the analysis is limited to manufacturing trade and hence disregards many IP-related transactions that offer large mispricing opportunities (see e.g. GRUBERT (2003), DISCHINGER AND RiEDEL (2011), BEER AND LOEPRICK (2014)). Recently, DAVIES ET AL. (2018) reported similar evidence for France, stressing, however, that the lion's share of income shifting relates to a minority of only 400 multinational groups (and their export flows to tax haven economies).

A number of recent papers moreover suggest that the location of valuable intangible property is systematically distorted towards low-tax locations (see DISCHINGER AND RIEDEL (2011)). KARKINSKY AND RIEDEL (2012) use data on corporate patent holdings of European multinational firms and find that the location of patents across group affiliates strongly responds to tax incentives, with a $1 \%$-increase in the corporate tax rate lowering patent holdings by around 3.5\% (see Griffith, Miller, AND O’Connell (2014) and AlstadSÆTER ET Al. (2017) for similar evidence). BAUMANN ET AL. (2017) furthermore suggest that MNEs strategically relocate patents with above average value to tax havens.

Empirical evidence furthermore confirms that MNEs engage in debt-shifting behaviour. While both MNEs and NEs have an incentive to shield their profits from taxation by debt financing, MNEs may additionally inject equity into low-tax subsidiaries, which then lend to high-tax affiliates and strip-out tax-deductible interest without raising the group's overall debtto-equity ratio (and hence its bankruptcy risk). Existing papers test for debtshifting based on firm level data and by regressing affiliates' internal debtholdings on the host country's corporate tax rate or the tax differential to other group affiliates respectively (see e.g. ALTSHULER AND GRUBERT (2003), Desai, Foley, AND Hines (2004), BÜTTNER AND WAMSER (2013), MøEN ET AL. (2012)). ${ }^{15}$ Reported semi-elasticities are around 1, suggesting that a 10-percentage point increase in the local statutory tax rate is associated with a $10 \%$ increase of the affiliate's internal debt-ratio. ${ }^{16}$ As internal debt holdings tend to be small and the transferred income is the product of internal debt and the

15 While the credit donor in the group can commonly not be identified, finding a positive response of affiliates' internal debt to host country corporate tax increases plausibly captures debt shifting as only internal debt provided by low-tax affiliates reduces the MNE's tax burden (internal debt provided by higher-tax affiliates would increase it).

16 BÜTTNER AND WAMSER (2013) and MøEN ET AL. (2012) point out that internal debt-shifting incentives relate to the host country's corporate tax rate as well as to the corporate tax rate of the lowest-tax affiliate in the multinational group. 
interest rate, the estimates, overall, imply relatively small debt-shifting volumes (see e.g. BÜtTNER AND WAMSER (2013) and DHARMAPAla (2014)). A recent meta-analysis by HECKEMEYER AND OVERESCH (2017) confirms this notion (suggesting that debt-shifting makes up around 30\% of overall income shifting activities and mispricing of intra-firm trade makes up around $70 \%)^{17}$

\section{Conclusions}

Researchers have taken various routes to identify tax-motivated international income shifting. As MNEs have an incentive to hide avoidance activities from the public, identification approaches are indirect and rely on a number of assumptions, which - if violated - lead to biased estimates. Studies unanimously report qualitative evidence in line with international tax avoidance behaviour. The quantitative estimates vary across approaches though, with results at the lower (upper) end suggesting that MNEs transfer less than 5\% (30\% or more) of their income earned at high-tax affiliates to lower-tax entities. While the range of estimates is wide, academic evidence points to smaller shifting volumes in the population of (medium-sized and large) ${ }^{18}$ MNEs than recent media reports which feature groups with virtually no taxable income in high-tax countries (e. g. Daily Mail (2013), City AM (2014)). The most convincing empirical evidence has been presented by academic studies that investigate specific profit shifting channels as their empirical tests are more direct and offer less room for results being driven by mechanisms unrelated to income shifting. The latter studies are still scarce though and evidence on some BEPS strategies, e.g. hybrid mismatch arrangements, is completely missing. It is thus too early to draw final conclusions on the quantitative importance of international tax avoidance activities. Whether the upcoming years will see progress in quantifying BEPS (and assessing the effectiveness of anti-shifting provisions in limiting multinational income shifting behaviour) will critically depend on whether researchers can access high-quality data that allows identifying MNEs' reported tax bases, tax

17 Specifically, Heckemeyer and Overesch (2017) compare the estimates of papers that determine the corporate tax sensitivity of operating income (EBIT) with papers that determine the corporate tax sensitivity of pre-tax profit (which comprise operating and financial income). The latter captures both, transfer pricing and the strategic use of debt, whereas the former isolates profit shifting through the mispricing of intra-firm trade (and relocation of valuable IP).

18 While some studies rely on data for the population of MNEs in specific countries or host regions, most papers make use of accounting data from private data providers which include medium-sized and large firms only. 
liabilities/tax payments and business activity across group locations. While tax authorities in many countries have so far been restrictive in providing researchers access to anonymized corporate tax return and audit data, changing that policy might help to close prevailing knowledge gaps on the size of international tax avoidance.

\section{References}

Alstadsater, A., S. Barrios, G. Nicodeme, A. Skonieczna and A. Vezzani (2017): Patent Boxes Design, Patents Location and Local R\&D. Paper presented 65th Economic Policy Panel Meeting, March 2017.

Altshuler, R. and H. Grubert (2003): Repatriation Taxes, Repatriation Strategies and Multinational Financial Policy, Journal of Public Economics 87, 73-107.

AltShUler, R. and H. GRUBert (2006): Governments and Multinational Corporations in the Race to the Bottom, Tax Notes International 41(5), 459-474.

Baumann, M., T. Böhm, B. Knoll and N. Riedel (2017): Taxes and Corporate Profit Shifting: Empirical Evidence. University of Bochum, mimeo.

BeER, S. and J. LoEPRICK (2014): Profit Shifting: Drivers of Transfer (Mis)Pricing and the Potential of Countermeasures. International Tax and Public Finance, forthcoming.

Bernard, A., B. Jensen and P. SCHOTt (2006): Transfer Pricing by U.S.-based Multinational Firms, NBER Working Paper 12493.

BOMBARDINI, M. (2008): Firm Heterogeneity and Lobby Participation, Journal of International Economics 75(2), 329-348.

BüttNer, T. and G. WAMSER (2013): Internal Debt and Multinationals' Profit Shifting - Empirical Evidence from Firm-Level Panel Data, National Tax Journal 66, 63-95.

City AM (2014): Facebook's 3,169 Pound UK Corporate Tax Bill in 2013 was Less than a Zone 1-9 Yearly London Travel Card, October 31, 2014.

CLAusing, K. A. (2003): Tax-Motivated Transfer Pricing and US Intrafirm Trade Prices, Journal of Public Economics 87, 2207-2223.

Clausing, K. A. (2009): Multinational Firm's Tax Avoidance and Tax Policy, National Tax Journal 62, 703-725.

Clausing, K. A. (2011): The Revenue Effects of Multinational Firm Income Shifting, Tax Notes, March 28, 2011.

Collins, J. H. and D. SHACKELfoRd (1997): Global Organizations and Taxes: An Analysis of the Dividend, Interest, Royalty, and Management Fee Payments between U.S. Multinationals' Foreign Affiliates, Journal of Accounting and Economics 24(2), 151-173.

CRISTEA, A. and D. NGuYen (2016): Transfer Pricing by Multinational Firms: New Evidence from Foreign Firm Ownerships, American Economic Journal: Economic Policy 8(3), 170-202.

Daily Mail (2013): Starbucks Finally Pays 5 Million Pounds of UK Tax for the First Time in Five Years after Six Months of Outrage despite 253 Million Pounds Profit in Just Three Months, June 23, 2013.

Davies, R., J. Martin, M. Parenti and F. Toubal (2018): Knocking on Tax Haven's Door: Multinational Firms and Transfer Pricing, Review of Economics and Statistics, forthcoming. https://www.mitpressjournals.org/doi/abs/10.1162/REST_a_00673. 
Desal, M., F. FoleY and J. HINES (2003): Chains of Ownership, Regional Tax Competition, and Foreign Direct Investment, in: H. Herrmann and R. Lipsey (eds.) Foreign Direct Investment in the Real and Financial Sector of Industrial Countries. Springer-Verlag, Berlin, Heidelberg, 61-98.

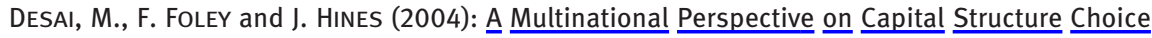
and Internal Capital Markets, Journal of Finance 59, 2451-2487.

DesAl, M., F. FoleY and J. HINES (2006): The Demand for Tax Haven Operations, Journal of Public Economics 90, 513-531.

Dharmapala, D. (2014): What Do We Know about Base Erosion and Profit Shifting? A Review of the Empirical Literature, CESifo Working Paper No. 4612.

Dharmapala, D. and J. Hines (2009): Which Countries Become Tax Havens?, Journal of Public Economics 93, 1058-1068.

Dharmapala, D. and N. Riedel (2013): Earnings Shocks and Tax-Motivated Income Shifting: Evidence from European Multinationals, Journal of Public Economics 97, 95-107.

Dischinger, M., B. KNOLL and N. Riedel (2014): The Role of Headquarters in Multinational Profit Shifting Strategies, International Tax and Public Finance 21, 248-271.

DischingeR, M. and N. Riedel (2011): Corporate Taxes and the Location of Intangible Assets within Multinational Firms, 2011, Journal of Public Economics 95, 691-707.

Dowd, T., P. LANDefeld and A. Moore (2017): Profit Shifting of U.S. Multinationals, Journal of Public Economics 148, 1-13.

Egger, P., W. EgGeRT and H. Winner (2010): Saving Taxes through Foreign Plant Ownership, Journal of International Economics 81, 99-108.

FINKE, K. (2013): Tax Avoidance of German Multinationals and Implications for Tax Revenue Evidence from a Propensity Score Matching Approach, mimeo.

Griffith, R., H. Miller and M. O'Connell (2014): Ownership of Intellectual Property and Corporate Taxation, Journal of Public Economics 112, 12-23.

GRUBERT, H. (2003): Intangible Income, Intercompany Transactions, Income Shifting, and the Choice of Location, National Tax Journal 56, 221-242.

The Guardian (2009): FTSE 100: What they Make, what they Pay, http://www.guardian.co.uk/ business/series/tax-gap

The Guardian (2013): Tax Avoidance: How to Change Corporate Behaviour, May 19, 2013.

GUMPERT, A., J. Hines and M. SCHNitzer (2011), The Use of Tax Havens in Exemption Regimes, NBER Working Paper No. 17644.

HeCKemeYer, J. and M. OVERESCH (2017): Multinationals' Profit Response to Tax Differentials: Effect Size and Shifting Channels, Canadian Journal of Economics 50(4), 965-994.

HMRC (2014): Measuring Tax Gaps 2014 Edition, Tax Gap Estimates for 2012-13, London. IMF (2013): Fiscal Monitor October 2013, Taxing Times. International Monetary Fund, Washington. JohanneSen, N. (2014): Tax Avoidance with Cross-Border Hybrid Instruments, Journal of Public Economics 114, 40-52.

KARKINSKY, T. and N. RIEDEL (2012): Corporate Taxation and the Location of Patents within Multinational Firms, 2012, Journal of International Economics 88(1), 176-185.

MilleR, H. (2013): Corporate Tax, Revenues and Avoidance, IFS Budget Analysis, in: C. Emmerson, P. Johnson and H. Miller (eds.) IFS Green Budget: February 2013 Chapter 10. Institute for Fiscal Studies, London.

Møen, J., D. SChindler, G. SChjelderup and J. Tropina (2012): International Debt Shifting: Do Multinationals Shift Internal or External Debt?, Paper Presented at the Congress oft he German Economic Association 2013. 
MurPhy, R. (2012): Closing the European Tax Gap, A Report for Group of the Progressive Alliance of Socialists \& Democrats in the European Parliament.

OECD (2015): Measuring and Monitoring BEPS, Action 11-2015 Final Report. OECD Publishing, Paris.

Sullivan, M. (2004): Data Show Dramatic Shift of Profits to Tax Havens, Tax Notes, 1190-1200. The Telegraph (2012): Google's Tax Avoidance Is Called ‘Capitalism', Says Chairman Eric Schmidt, December 12, 2012.

TUC (2008): The Missing Billions, Trade Union Congress, United Kingdom, http://www.tuc.org. uk/touchstone/missingbillions/1missingbillions.pdf

WeichenRIEDER, A. and J. Mintz (2008): What Determines the Use of Holding Companies and Ownership Chains? Oxford University Centre for Business Taxation Working Paper Series No. 803. 